\title{
An Investigation of Academic Self-Efficacy Perceptions of Primary Mathematics Teacher Candidates
}

\author{
Cahit Taşdemir ${ }^{1}$ \\ ${ }^{1}$ Bitlis Eren University, Tatvan Vocational School, Tatvan/ Bitlis, Turkey \\ Correspondence: Bitlis Eren University, Tatvan Vocational School, Tatvan/ Bitlis, Turkey. E-mail: \\ ctasdemir@beu.edu.tr
}

Received: February 5, 2019

Accepted: February 26, 2019 Online Published: March 8, 2019

doi:10.5539/hes.v9n2p72

URL: https://doi.org/10.5539/hes.v9n2p72

\begin{abstract}
The aim of this study was to investigate the academic self-efficacy perceptions of primary school mathematics teacher candidates according to different variables. For this purpose, the "Academic Self-Efficacy Scale", which was developed by Jerusalem and Schwarz (1981) to measure the academic self-efficacy beliefs of mathematics teacher candidates, which was adapted to Turkish by Yılmaz, Gürçay and Ekici (2007) and validated by the reliability and validity scale, were used as data collection tools. The study was conducted in the fall semester of 2017-2018 academic year. The sample of the study consists of 157 teacher candidates studying at the 1st, 2nd, 3rd and 4th years of the Elementary Mathematics Teaching Program of the Faculty of Education at a state university. Independent sample t-test and ANOVA were used for the analysis of collected information. As a results of data analysis, student's academic self efficacy perceptions were found generally high. In addition, it was concluded that the mean scores of academic self-efficacy perceptions of mathematics teachers did not show a statistically significant difference according to their gender and grade level, but there was a significant difference between the age, whether they willingly chose what they are studying or not and mathematics achievement groups.
\end{abstract}

Keywords: mathematics teacher candidates, self-efficacy, academic self-efficacy, teacher education

\section{Introduction}

The most important element of the educational system is the teacher, and the success of the educational system depends mainly on the qualifications of teachers operating the system. The teacher of the 21 st century has undertaken such duties as providing learning, classroom management, assessment, confidence building, professional mastery as well as being a family member and a community leader. Accordingly, the teacher should manage the classroom well, present the content that he/she will teach effectively, ensure learning, assess the student achievement impartially, have knowledge, provide guidance, have professional effectiveness, follow ethics and give confidence (Saracaloğlu, 2006). The training of qualified individuals of the future depends on the training of today's qualified teachers. The concept of self-efficacy is one of the important concepts that are dealt with in the context of the qualifications that teacher candidates should have in the 21st century (Frrat, 2010).

The perception of self-efficacy involves organizing and effectively applying cognitive, social, emotional and behavioral skills that are necessary to accomplish a task. In addition, the perception of self-efficacy is not only about the multiplicity of the individual's skills, but also about what the individual believes he or she can do with these skills in a given condition (Bandura, 1977). Self-efficacy belief is the belief of self-confidence that individuals create in themselves while carrying out an activity (Siegle, 2003). The perception of self-efficacy also affects the way people think and their emotional reactions. Individuals with a high level of self-efficacy can be more comfortable and productive when faced with tasks that have a high level of difficulty. Those who have low self-efficacy belief, on the other hand, believe that their task is even harder than it is in reality. This type of perception increases anxiety and stress, while narrowing the perspective that one needs to solve a problem in the best possible way. For this reason, self-efficacy belief strongly affects the level of individuals' success (Pajares, 2002; cited in, Üredi \& Üredi, 2006)

Teacher's self-efficacy perceptions is defined as the teacher's belief about his/her ability to demonstrate the ability to influence the students or to perform their duties. (Aston, 1984; cited in Ekici, 2006) Academic self-efficacy refers to an individual's belief in accomplishing an academic task successfully. Many studies have 
been conducted indicating the importance of have higher academic self-efficacy for individuals and especially that students' academic self-efficacy increases their academic success (Bandura, 1997; Pajares, 1997; cited in Yılmaz, Gürçay \& Ekici, 2007). Individuals with high academic self-efficacy are able to adapt to their environment more easily and strive to accomplish the tasks assigned to them. This continues in the form of a loop. In other words, the student is able to work hard and achieve success without being overwhelmed by a problem and have positive emotions as a result, and thus their academic self-efficacy increases. Likewise, a student with strong academic self-efficacy is able to respond to the question and not give up because of his/her positive belief in accomplishing academic tasks and his/her belief that he/she can answer the question (Yalnız, 2014).

In the literature review, it was found that many studies were conducted on teacher candidates' self-efficacy and academic self-efficacy beliefs (Çuhadar, Gündüz \& Tanyeri, 2013; Özsüer, et al., 2011; Tunca \& Alkın-Şahin, 2014; Fırat, 2010; Yenilmez, 2016; Ekici, 2012; Oğuz, 2012; Yağcı \& Aksoy, 2015, Yalmancı \& Aydın, 2014; Tabancalı \& Çelik, 2013; Azar, 2010; Korucu \& Çınar, 2017; Alemdağ et al., 2014; Aydın et al., 2014; Demirtaş et al., 2011; Saracaloğlu et al., 2013; Güzel, 2017; Ünlüet al., 2017; Donmuş et al., 2017; Altunçekiç et al., 2005; Erdem, 2008; Senemoğlu et al., 2009; Taşkın \& Hacıömeroğlu, 2010; Yaşar et al., 2006; Zajacova et al., 2005; Bonk, 2004; Schunk \& Pajares, 2002; Taylor, 2014; Bandura, 1997; Pajares, 1996; Bong \& Clark, 1999; Gore, 2006). However, there are a limited number of studies on academic self-efficacy beliefs of mathematics teacher candidates. This situation makes it even more important to study the self-efficacy beliefs of mathematics teacher candidates. Because, a teacher who is not competent in his/her field can not be expected to give confidence to his/her students and to establish an authority based on respect. As the self-efficacy reflects the individual's judgment, it is expected that well-educated class and first all of all mathematics teachers would have a high level of self-efficacy (Dede, 2008). According to a study conducted by Chan (2003), individuals having a high self-efficacy level provide more efficient education than those with low self-efficacy and have less stress during education. For this purpose, in order to educate the teachers of the future and give them a good mathematics education, it is thought that the determination of prospective teachers' academic self-efficacy beliefs studying in the Department of Mathematics will make a significant contribution to the literature. Therefore, student's academic self-efficacy perceptions were examined in terms of different variables.

\subsection{Research}

\subsection{Aim of Research}

The aim of this study is to examine the academic self-efficacy beliefs of mathematics teacher candidates according to their gender, grade, age, mathematics achievement level and whether they willingly chose this department. In line with this purpose, the answers to the following questions were sought.

1. What is the level of academic self-efficacy perceptions of mathematics teachers?

2. Do the academic self-efficacy beliefs of mathematics teacher candidates differ significantly according their gender, grade, age, mathematics achievement level and their willingness when they chose this department?

\section{Method}

\subsection{Research Model}

In the study, general screening model of quantitative research models was used to determine academic self-efficacy beliefs of mathematics teacher candidates. The screening model is a research approach aimed at describing a situation in the past or present as it exists (Karasar, 2002).

\subsection{Study Group}

The study group of the research consisted of 85 teacher candidates who are studying in the 1st, 2nd and 3rd year of Primary Mathematics Education Department of an Education Faculty of a University located in Eastern Anatolia region during the spring semester of the 2017-2018 academic year. \%45,9 of the sample group were female $(\mathrm{N}=72)$ and $\% 54.1$ were male $(\mathrm{N}=85) .28 .7 \%$ of the teacher candidates $(\mathrm{N}=45)$ were studying in $1 \mathrm{st}$ year, $21.7 \%(\mathrm{~N}=34)$ were in 2 nd year, $25.5 \%(\mathrm{~N}=40)$ were in 3 rd year and $24,2 \%(\mathrm{~N}=38)$ were in 4th year. $23.6 \%(\mathrm{~N}=37)$ of the teacher candidates were between $18-19$ years old, $50 \%(\mathrm{~N}=79)$ were between $20-21$ years old and $26.1 \%(\mathrm{~N}=41)$ were 22 and over.

\subsection{Data Collection Tools}

In the research, the personal data form created by the researcher and the "Academic Self-efficacy Scale", which was developed by Jerusalem and Schwarz (1981) to measure the academic self-efficacy beliefs of mathematics teacher candidates, which was adapted to Turkish by Yılmaz, Gürçay and Ekici (2007) and validated by the 
reliability and validity scale, were used as data collection tools. The Cronbach Alpha coefficient for reliability of the scale was calculated as 0.79. In the study, the Cronbach Alpha internal consistency coefficient for the reliability of the scale was found as 0.65 . Assumed that the intervals are equal in the evaluation of responses to the items in the questionnaire and the score range for the arithmetic average was calculated as 0.75 . Score range $=($ Highest value - Lowest value $) / 4=3 / 4=0,75)$. According to this calculation, the range of arithmetic averages is: "1.00 - 1.75= It does not reflect me at all", " $1.76-2.50=$ It reflects me very little", " $2.51-3.25=$ It reflects me" and $3.26-4.00=$ It reflects me perfectly". In the analysis of the data, evaluations were made based on these score ranges.

\subsection{Analysis of the Data}

In accordance with the general purpose of the study, SPSS 17.0 package program was used for the necessary statistical analysis of the data collected with the questionnaire. The score of each teacher candidate participating in the survey was calculated based on the positive or negative choice they selected, and these scores were divided by the number of items and converted into scores ranging from 1-4. Thus, it was ensured that the teacher candidates' scores were compared and equivalents of their answers were easily visible. In the analysis of the data, independent sample t-test was used for two variables and one-way variance analysis (ANOVA) was used for more than two variables. The result of the homogeneity test of variance was $p>0.05$. As a result, since the basic assumption of variance analysis is provided, we can state that the results obtained from the analysis of variance are healthy (Kalayc1, 2006). For this reason, parametric tests were used to analyze the data. In the case of the significance of the value of $\mathrm{F}$, Scheffe test was used to determine the difference between the groups. The significance level was taken as 0.05 in the statistical analysis.

\section{Results}

In this section, the findings obtained based on the data collected in the direction of the purpose of the study are presented.

The minimum, maximum, mean and standard deviation scores of mathematics teacher candidates' academic self-efficacy perceptions are given on Table 1.

Table 1. Academic Self-efficacy Perception Scores of Math Teacher Candidates

\begin{tabular}{lcllcc}
\hline Variable & $\mathbf{N}$ & Min. & Max. & $\bar{x}$ & S \\
\hline Academic self-efficacy & 157 & 1.710 & 4.00 & 3.043 & 0.474 \\
\hline
\end{tabular}

When Table 1 is examined, the mean score of the academic self-efficacy beliefs of the mathematics teacher candidates is found as $\bar{x}=3.043$ and the standard deviation is found as $S=0,474$. This result corresponds to the level of "It reflects me" according to the scale. When academic self-efficacy beliefs are evaluated as "low, moderate, high", it can be considered that teacher candidates have high academic self-efficacy beliefs.

The results of the independent sample t-test applied to determine whether academic self-efficacy beliefs of mathematics teachers show a significant difference according to gender are given on Table 2.

Table 2. T-test Results of Mathematics Teacher Candidates' Academic Self-efficacy Perceptions Scores According to Gender Variable

\begin{tabular}{lcccccc}
\hline Gender & $\mathbf{N}$ & $\bar{x}$ & $\mathbf{S}$ & $\mathbf{s d}$ & $\mathbf{t}$ & $\mathbf{p}$ \\
\hline Female & 72 & 3.066 & 0.433 & 155 & 0.550 & .583 \\
Male & 85 & 3.024 & 0.509 & & & \\
\hline
\end{tabular}

When Table 1 is examined, the mean scores of the academic self-efficacy perceptions of the mathematics teacher candidates did not show any significant difference according to the gender variable. $\left[t_{(155)}=, 550, p>05\right]$. Hence, it is possible to suggest that the gender variable does not have a significant impact on teacher candidates' academic self-efficacy perceptions scores. The average scores of female and male teacher candidates are almost the same. It is observed that the average scores of females is $\bar{x}(=3,066)$ and the average scores of males is $(\bar{x}=3,024)$.

Table 3 shows whether the results of academic self-efficacy perceptions of mathematics teachers show a significant difference according to their grade. 
Table 3. Arithmetic Mean and Standard Deviation Results of Academic Self-efficacy Perceptions of Mathematics Teachers According to Their Grade Level

\begin{tabular}{|c|c|c|c|}
\hline Grade Level & $\mathrm{N}$ & $\bar{x}$ & Ss \\
\hline 1. Grade & 45 & 2.964 & 0.586 \\
\hline 2. Grade & 34 & 2.970 & 0.480 \\
\hline 3. Grade & 40 & 3.092 & 0.396 \\
\hline 4. Grade & 38 & 3.150 & 0.380 \\
\hline Total & 157 & 3.043 & 0.474 \\
\hline
\end{tabular}

When Table 3 is examined, the mean scores of teacher candidates' academic self-efficacy beliefs were found as: 1st grade $(\bar{x}=2.964), 2$ nd grade $(\bar{x}=2.97)$, 3rd grade $(\bar{x}=3.092)$ and 4th grade $(\bar{x}=3.150)$. According to these findings, the academic self-efficacy score of teacher candidates increased with the grade level. in other words, there is a difference between the grades. The findings of the Scheffe test results conducted to test whether this difference is statistically significant are given in Table 4.

Table 4. ANOVA Test Results Related to The Scores of Teacher Candidates' Academic Self-efficacy Beliefs by Grade Level

\begin{tabular}{lcrccc}
\hline Source of Variance & Sum of Squares & sd & Mean of Squares & F & P \\
\hline Between groups & 0.990 & 3 & 0.330 & 1.477 & 0.223 \\
Within groups & 34.206 & 153 & 0.224 & & \\
Total & 35.197 & 156 & & & \\
\hline
\end{tabular}

When Table 4 is examined, a statistically significant difference was not found among the mean scores of teacher candidates' academic self-efficacy perceptions $\left[\mathrm{F}_{(3-153)}=, 223, \mathrm{p}>0.05\right]$.

Table 5 illustrates whether academic self-efficacy beliefs of mathematics teachers show a significant difference according to age.

Table 5. Arithmetic Mean and Standard Deviation Results of Mathematics Teacher Candidates' Academic Self-efficacy Perceptions Scores by Age

\begin{tabular}{llll}
\hline Variable & N & $\bar{x}$ & ss \\
\hline Age 18-19 & 37 & 2.877 & 0.430 \\
Age 20-21 & 79 & 3.062 & 0.474 \\
Age 22 years and over & 41 & 3.155 & 0.484 \\
Total & 157 & 3.043 & 0.474 \\
\hline
\end{tabular}

When Table 5 is examined, it is seen that mathematics teacher candidates' academic self-efficacy belief total mean score according to age is $(\bar{x}=3,043)$. The mean scores of teacher candidates' academic self-efficacy beliefs according to their age group were found as: For $18-19$ age group $(\bar{x}=2.877)$ for the age group 20-21 $(\bar{x}=3.062)$ and for ages 22 and over $(\bar{x}=3,155)$. According to these findings, the academic self-efficacy belief mean scores of the teacher candidates who are 22 years old and over are higher than that of the other age groups. The findings of Scheffe test results conducted to test whether this difference is statistically significant are given in Table 6 .

Table 6. ANOVA Test Results of Academic Self-efficacy Beliefs of Mathematics Teacher Candidates According to Age Variable

\begin{tabular}{lcrcccc}
\hline Source of Variance & Sum of Squares & sd & Mean of Squares & F & P & Difference \\
\hline Between groups & 1.568 & 2 & 0.784 & 3.591 & .030 & $1-2$ \\
Within groups & 33.628 & 154 & 0.218 & & & \\
Total & 35.197 & 156 & & & & \\
\hline
\end{tabular}

\section{Age 22 and over 2.18-19 years old}

When Table 6 is examined, no statistically meaningful significance was found between academic self-efficacy belief scores of mathematics teacher candidates by age. $\left[\mathrm{F}_{(2-154)}=3,591, \mathrm{p}<0.05\right]$. According to the results of the Scheffe test which was used to determine which age groups had this significant difference, it was found to be between age 22 and 18-19. However, the difference was significant in favor of age group 22 and above. 
Table 7 shows whether the academic self-efficacy beliefs of mathematics teachers show a significant difference according to their choosing the program willingly.

Table 7. Results of T-test Of Mathematics Teachers' Academic Self-efficacy Beliefs According to Their Choosing The Program Willingly

\begin{tabular}{lrccccc}
\hline Choosing the Program Willingly or Not & $\mathbf{N}$ & $\overline{\boldsymbol{x}}$ & $\mathbf{S}$ & $\mathbf{s d}$ & $\mathbf{t}$ & $\mathbf{p}$ \\
\hline Yes & 121 & 3.201 & 0.391 & 155 & 2.311 & .022 \\
No & 36 & 2.996 & 0.488 & & & \\
\hline
\end{tabular}

Yes: Choosing the program willingly No: Choosing the program not willingly

According to Table 7, it was determined that the mean scores of the academic self-efficacy beliefs of the prospective mathematics teachers did not show any significant difference according to whether they have selected the program willingly or not. [ $\left.\mathrm{t}_{(155)}=2.311, \mathrm{p}<.05\right]$. This meaningful difference is in favor of teacher candidates who have chosen the program willingly.

Table 8 shows whether the academic self-efficacy beliefs of mathematics teachers show a significant difference according to their mathematics achievement level.

Table 8. Arithmetic Mean and Standard Deviation Results for Academic Self-efficacy Perceptions Scores of Mathematics Teacher Candidates according to Mathematics Achievement Levels

\begin{tabular}{llcc}
\hline Mathematics Achievement Level & N & $\overline{\boldsymbol{x}}$ & SS \\
\hline Weak & 15 & 2.548 & 0.408 \\
Moderate & 16 & 2.530 & 0.327 \\
Good & 13 & 2.973 & 0.406 \\
Excellent & 113 & 3.189 & 0.410 \\
Total & 157 & 3.043 & 0.474 \\
\hline
\end{tabular}

When Table 8 is examined, academic self-efficacy belief scores of teacher candidates according to mathematical achievement groups are: Week $(\bar{x}=2.548)$, Moderate $(\bar{x}=2.530)$, Good $(\bar{x}=2.973)$ and Excellent $(\bar{x}=3.189)$. According to these findings, it is observed that the teacher candidates with excellent mathematics achievement also have higher academic self-efficacy belief scores than the teacher candidates with good, moderate and weak mathematics achievement. According to this study, teachers' academic self-efficacy perceptions scores differ according to the mathematics achievement variable. The findings of the Scheffe test results conducted to test whether this difference is statistically significant are given in Table 9.

Table 9. ANOVA Test Results of Academic Self-efficacy Beliefs Scores of Mathematics Teacher Candidates Accordingly Mathematics Achievement Variable

\begin{tabular}{lllcccc}
\hline Source of Variance & Sum of Squares & sd & Mean of Squares & F & P & Difference \\
\hline Between groups & 10.352 & 3 & 3.451 & 21.251 & 0,000 & $1-3$ \\
& & & & & & $1-4$ \\
Within groups & 24.844 & 153 & 0.162 & & $2-3$ \\
Total & 35.197 & 156 & & & $2-4$ \\
\hline
\end{tabular}

$\begin{array}{lll}\text { 1. Excellent 2. Good } \quad \text { 3. Moderate } \quad \text { Weak } & \end{array}$

When Table 9 is examined, a statistically significant difference was found among academic self-efficacy beliefs scores of teacher candidates according to mathematics achievement levels $\left[\mathrm{F}_{(3-153)}=21.251, \mathrm{p}<0.05\right]$. According to the results of the Scheffe test which was used to determine which achievement groups had this significant difference, a significant difference was found between the academic self-efficacy belief scores of the candidate teachers who have excellent mathematics achievement and the candidate teachers whose math achievement is moderate and weak in favor of candidate teachers whose mathematics achievement is excellent. Again a significant difference was found between the academic self-efficacy belief scores of candidate teachers with good mathematics achievement and the candidate teachers who have moderate and weak mathematics achievement in favor of candidate teachers whose mathematics achievement is good. Hence, it can be said that teacher candidates with low mathematics achievement have low academic self-efficacy beliefs scores, while teacher candidates with high mathematics achievement have high academic self-efficacy beliefs scores. 


\section{Discussion and Conclusion}

In this section, the results of this research and the results of other researches are discussed.

In this study, it was determined that the self-efficacy perceptions of mathematics teacher candidates correspond to "It reflects me" level according to the score range of the scale based on their academic self-efficacy perceptions. Thus, it is possible to assume that the teacher candidates' academic self-efficacy perceptions are generally high. Hence, it can be assumed that the teacher candidates have a self-efficacy perception that they can achieve an academic task assigned to them. The result of this study is similar to the result of study carried out by Yilmaz et al. (2007) and Oğuz (2012) with the primary class teacher candidates.

In the study, it was determined that the mean scores of the academic self-efficacy perceptions of the mathematics teacher candidates did not show a statistically significant difference according to the gender variable $\left[\mathrm{t}_{(155)}=, 550\right.$, $\mathrm{p}>$.05]. According to this finding, it is possible to state that the gender variable has no significant effect on the academic self-efficacy perceptions of mathematics teacher candidates. In other words, both male and female teacher candidates have the same level of self-efficacy perceptions about accomplishing an academic task, in terms of seeing themselves capable and confidence in their abilities. The result of this study is similar to the results of studies carried out by (Yalmancı \& Aydın, 2014; Demir \& Ar1, 2013; Şahin et al., 2011; Özsüer et al., 2011; Taşkın \& Hacıömeroğlu, 2010; Donmuş et al., 2017; Oğuz, 2012; Çuhadar et al., 2013). However, there are also studies showing that academic self-efficacy perception level differs significantly by gender (F1ra, 2010; Yağcı \& Aksoy, 2015; Alemdağ et al., 2014; Tunca \& Alkın-Şahin, 2014; Schunk \& Pajares, 2002; Bong, 2004). According to these results, it can be said that the effect of gender variable on academic self-efficacy perception varies.

One of the important results obtained in the study is that there is no statistically significant difference between the scores of academic self-efficacy perceptions of mathematics teacher candidates according to the grade level $\left[\mathrm{t}_{(3-153)}, 223, \mathrm{p}>0.05\right]$. However, it was determined that the academic self efficacy score of the teacher candidates increased with the grade level. That is, the 4th grade teacher candidates' academic self-efficacy perceptions are higher than those who teach in other classes. Among the reasons for the differentiation of academic self-efficacy levels as the levels of the class differ, the lessons taken by the prospective teachers can be shown. As the class levels increase, teacher candidates begin to take the subject of field knowledge. Especially the students of the last year have the knowledge of the basic courses they need and the majority of their field knowledge. The academic self-efficacy perceptions of the prospective teachers who were educated in the fourth year may have increased as a result of the trust given by having sufficient knowledge (Firat, 2010). Similarly, in their study, Tunca and Alkın-Şahin (2014), reported that the fourth grade students have higher academic self-efficacy perceptions than first grade students. As the reasons for this, they expressed the self-confidence they gained through more courses taken related to field knowledge and teaching profession knowledge, recognizing the methods of assessment and evaluation of lecturers related to the courses to be taken and their successfully completing the first three grades. According to Yağc1 and Aksoy (2015), studying in upper grades ensures that individuals have a higher sense of competence in dealing with academic tasks than someone who has just started school. Grade 4 students have more successful experiences in the three years they left behind. They have dealt with more difficulty and are more experienced. This result of the study is similar to the results of the study conducted by Y1lmaz et al. (2010), while contradicting the results of the studies conducted by (Fırat, 2010; Oğuz, 2012; Tunca \& Alkın-Şahin, 2014; Yağcı \& Aksoy, 2015; Yalmancı \& Aydın, 2014; Korucu \& Çınar, 2017).

In the study, it was determined that mathematics teacher candidates' academic self-efficacy perceptions showed a statistically significant difference according to age variable $\left[\mathrm{F}_{(2-154)}=3.591, \mathrm{p}<0.05\right]$. According to the results of the research, the academic self-efficacy perceptions mean scores of teachers aged 22 years and over were found to be significantly higher than that of other age groups. This may be due to the fact that candidate teachers' perception in accomplishing an academic task is higher as a result of the experience they have gained than that of the younger teacher candidates. This finding of the study is similar to the results of the studies conducted by (Oğuz, 2012; Korucu \& Çınar, 2017). However, it contradicts the results of study conducted by Yağcı and Aksoy (2015). In a study conducted by Tabancalı and Çelik (2013), it was determined that the academic self-efficacy beliefs of teacher candidates showed a significant difference in favor of teachers aged 20 and under.

In this study, it was determined that the academic self-efficacy perceptions of mathematics teacher candidates differ significantly depending on whether they willingly chose the program they study or not $\left[\mathrm{t}_{(155)}=2,311\right.$, $\mathrm{p}<.05]$. This meaningful difference is in favor of teacher candidates who have chosen the program willingly. This result is similar to the findings of the study conducted by Oğuz (2012) while contradicting the finding of study by Donmus et al. (2017). People doing their favorite jobs and professions is a situation that will increase their 
success in the profession from the beginning. And this may be a reason why the academic self-sufficiency of teacher candidates is high.

Another important finding in the study was that there was a statistically significant difference between the mean scores of the academic self-efficacy perceptions of mathematics teacher candidates according to their mathematics achievement level $\left[\mathrm{F}_{(3-153)}=21,251 \mathrm{p}<0.05\right]$. According to the results of the Scheffe test which was used to determine which achievement groups had this significant difference, a significant difference was found between the academic self-efficacy perception scores of the candidate teachers who have excellent mathematics achievement and the candidate teachers whose math achievement is moderate and weak in favor of candidate teachers whose mathematics achievement is excellent. Again a significant difference was found between the academic self-efficacy belief scores of candidate teachers with good mathematics achievement and the candidate teachers who have moderate and weak mathematics achievement in favor of candidate teachers whose mathematics achievement is good. Hence, it can be said that teacher candidates with low mathematics achievement have low academic self-efficacy perceptions and those with high mathematics achievement have high academic self-efficacy perceptions. This may be a reflection of the positive attitude of the teacher candidates who have high level of mathematics achievement and see themselves as academically competent in dealing with mathematical concepts, trusting their abilities This result of the research coincides with the results of the studies conducted by Yağcı and Aksoy (2015), Yenilmez (2016). In these studies, it was determined that when academic achievement of teacher candidates was high, their academic self-efficacy was also higher. This finding of the research contradicts the finding of the study carried out by Oğuz (2012) with primary school class teacher candidates. The reason why academic self-efficacy perceptions do not differ according to their academic achievement may be due to the use of data based on students' overall academic achievement average at University and their general academic self-efficacy perceptions. The same results may not be achieved when the level of success and self-efficacy related to a particular course or field is determined by special measurements. Meta analysis studies indicate that special academic self-efficacy measurements have a stronger effect on academic results than more general measurements (Zajacova, et al., 2005; cited in Oğuz, 2012).

As a result of the findings obtained from the study, the academic self-efficacy perceptions of mathematics teacher candidates were tried to be determined, and whether their academic self-efficacy perceptions varied significantly according to some variables. It was concluded that teacher candidates generally have high academic self-efficacy perceptions, that they did not differ significantly according to gender and grades, but that they did differ significantly according to age, whether they willing chose to study in the program and mathematics achievement groups. In future studies, academic self-efficacy perceptions of teacher candidates in different branches can be researched and compared with each other.

\section{References}

Alemdağ, C., Öncü, E., \& Yılmaz, A. K. (2014). Beden eğitimi öğretmeni adaylarının akademik motivasyon ve akademik öz yeterlikleri, Hacettepe Spor Bilimleri Dergisi, 25(1), 23-35.

Altunçekiç, A.,Yaman, S., \& Koray, Ö. (2005). Ögretmen Adaylarının Özyeterlik İnanç Düzeyleri ve Problem Çözme Becerileri Üzerine Bir Arastırma.(Kastamonu Örnegi).Kastamonu Egitim Dergisi, 13(1), 93-102.

Aydın, R., Ömür, Y. E., \& Argon, T. (2014). Öğretmen adaylarının öz yeterlik algıları ile akademik alanda arzularını erteleme düzeylerine yönelik görüşleri, Eğitim Bilimleri Dergisi, 40, 1-12.

Azar, A. (2010). Ortaöğretim fen bilimleri ve matematik öğretmeni adaylarının öz yeterlik inançları, Zonguldak Karaelmas Üniversitesi, Sosyal Bilimler Dergisi, 12, 235-252.

Bandura, A. (1977). Social Learning Theory. Englewood Cliffs NJ: Prentice Hall.

Bandura, A. (1997). Self efficacy:Exercises of control. New York, Freeman.

Bandura, A. (2002). Social cognitive theory in cultural context. Applied Psychology: An International Rewiew, 5l(2), 269-290. https://doi.org/10.1111/1464-0597.00092

Bong, M. (2004). Academic motivation in self-efficacy tast value, achievement goal orientations and attributional beliefs. The Journal of Educational Research, 97(6), 287-297. https://doi.org/10.3200/JOER.97.6.287-298

Bong, M., \& Clark, R. E. (1999). Comparison between self-concept and self-efficacy in academic motivation research. Educational psychologist, 34(3), 139-153. https://doi.org/10.1207/s15326985ep3403_1

Caymaz, B. (2008). Fen ve teknoloji ve sınıf öğretmeni adaylarının fen ve teknoloji okuryazarlığına ilişkin öz yeterlik algıları. Yayınlanmamış Yüksek Lisans Tezi, Hacettepe Üniversitesi, Sosyal Bilimler Enstitüsü, 
Ankara.

Chan, D. W. (2003). Multiple intelligences and perceived self-efficacy among chineese secondary school teacher's in Hong Kong. Educational Psychology, 23(5), 521-533. https://doi.org/10.1080/0144341032000123778

Çuhadar, C., Gündüz, Ş., \& Tanyeri, T. (2013). Bilgisayar ve öğretim teknolojileri eğitimi bölümü ders çalışma yaklaşımları ve akademik öz yeterlik algıları arasındaki ilişkinin incelenmesi, Mersin Üniversitesi, Eğitim Fakültesi Dergisi, 9(1), 251-259.

Dede, Y. (2008). Matematik Öğretmenlerinin Öğretimlerine Yönelik öz-yeterlik İnançları. Türk eğitim Bilimleri Dergisi, 6(4), 741-757.

Demir M.K., \& Arı E. (2013). Öğretmen adaylarının akademik güdülenme düzeylerinin çeşitli değişkenler açısından incelenmesi. Ĕ̈itimde Kuram ve Uygulama, 9(3), 265-279.

Demirtaş, H., Cömert, M., \& Özer, N. (2011). Öğretmen Adaylarının Özyeterlik İnançları ve Öğretmenlik Mesleğine İlişkin Tutumları. Eğitim ve Bilim Cilt 36, Sayı 159

Donmuş, V., Akpınar, B., \& Eroğlu, M. (2017). Öğretmen adaylarının akademik öz yeterlikleri ve mesleki kaygıları arasındaki ilişkinin incelenmesi, Mustafa Kemal Üniversitesi, Sosyal Bilimler Enstitüsü Dergisi, 37(14), 1-13.

Ekici, G. (2006). Meslek lisesi öğretmenlerinin öğretmen öz-yeterlik inançları üzerine bir araştırma. Eğitim araştırmaları, 8, 87-96.

Ekici, G. (2012). Akademik Öz-yeterlik Ölçeği: Türkçeye Uyarlama, Geçerlik ve Güvenirlik Çalışması. Hacettepe Üniversitesi, Eğitim Fakültesi Dergisi, 43, 174-185.

Erdem, M. (2008). Karma öğretmenlik uygulaması süreçlerinin öğretmen adaylarının öğretmenlik öz yeterlik ve epistemolojik inançlarına etkisi. Ĕgitim Araştırmaları Dergisi (Eurasian Journal of Educational Research), 30, 81-98.

Fırat, D. Ş. (2010). Sınıf öğretmeni adaylarının akademik öz yeterlik algılarının çeşitli değişkenler açısından incelenmesi, Abant İzzet Baysal Üniversitesi Dergisi, 10(1), 69-77.

Gore, P. A. (2006). Academic Self-Efficacy as a Predictor of College Outcomes: Two Incremental Validity Studies. Journal of Career Assessment, 14(1), 92-115. https://doi.org/10.1177/1069072705281367

Güzel, H. (2017). Lise öğrencilerinin akademik öz yeterlik inanç düzeylerinin internet kullanımı ve bazı değişkenler açısından incelenmesi, Uluslararası Ĕ̆itim Bilimleri Dergisi, 4(11), 225-245.

Jerusalem, M., \& Schwarzer, R. (1981). Fragebogen zur Erfassung von "Selbstwirksamkelt. Skalen zur Befindlichkeit und Personenlichket In R. Schxarzer (Hrsg.). (Forschungsbericht No.5). Berlin: Frele Universitaet, Institut fer Psychologie.

Kalaycı, Ş. (2006). SPSS Uygulamalı Çok Değişskenli İstatistik Teknikleri (2. Baskı), Asil yayın Dağıtım Ltd. Şti, Ankara.

Karasar, N. (2002). Bilimsel Araştırma Yöntemi: Kavramlar, İlkeler, Teknikler, 3A Araştırma Eğitim Danışmanlık Ltd, Ankara.

Korucu, A. T., \& Çınar, D. (2017). Eğitim Fakültesi öğrencilerinin Akademik öz yeterlik durumlarının incelenmesi, Yüzüncü Yıl Üniversitesi, Eğitim Fakültesi Dergisi, 14(1), 73-101.

Kuzgun, Y. (2003). Meslek Rehberliği ve Danışmanlığına Giriş, Nobel Yayınları, s. 54.

Oğuz, A. (2012). Sınıf öğretmeni adaylarının akademik öz yeterlik ianançları, Anadolu Journal of Educational Sciences International, 2(2), 15-28.

Özsüer, S., İnal, G., \& Ergün, M. (2011). Afyon Kocatepe Üniversitesinde öğrenim gören öğrencilerin akademik öz yeterlik inanç düzeylerinin incelenmesi, Afyon Kocatepe Üniversitesi, Sosyal Bilimler Dergisi, 13(2), 114-125.

Pajares, F. (1996). Self-Efficacy Beliefs in Academic Settings. Review of Educational Research, 66, $543-578$. https://doi.org/10.3102/00346543066004543

Şahin, H., Gülay Ogelman, H., \& Ekici, H. (2011). Okul öncesi öğretmen adaylarının akademik öz-yeterlik düzeylerine etki eden faktörlerin değerlendirilmesi. Çăgdaş Ĕ̆itim Dergisi, 36(389), 13-22.

Saracaloğlu, A. S. (2006). 21. Yüzyılda öğretmen adaylarının nitelikleri. Atatürk ve Cumhuriyete Armă̆an, 1, 
253-290.

Saracaloğlu, A. S., Yenice, N., \& Özden, B. (2013). Fen bilgisi, Sosyal Bilgiler ve Sınıf öğretmeni adaylarının öğretmen öz- yeterlik algılarının ve akademik kontrol odaklarının incelenmesi, Pamukkale Üniversitesi, Eğitim Fakültesi Dergisi, 34, 227-250.

Schunk, D. H., \& Pajares, F. (2002). The Development of Academic Self-Efficacy. In a. Wigfield, J.S. Eccles. Development and Achievement Motivation. California, Academic Press. https://doi.org/10.1016/B978-012750053-9/50003-6

Senemoğlu, N., Demirel, M., Yağc1, E., \& Üstündağ, T. (2009). Elementary school teachers' self-efficacy beliefs: A Turkish case. Humanity \& Social Sciences Journal, 4(2), 164-171.

Siegle, D. (2003). Influencing Student Mathematics self-Effcacy through Teacher Training Paper Presented at the Annual Meeting of the Ameican Research Association, Chicago, Il.

Tabancalı, E., \& Çelik, K. (2013). Öğretmen adaylarının akademik öz-yeterlikleri ile öğretmen öz-yeterlilikleri arasındaki ilişki. International Jounal of Human Sciences, 10(1), 1167-1184.

Taşkın, Ç. Ş., \& Hacıömeroğlu, G. (2010). Öğretmen öz yeterlik ölçeğinin Türkçe'ye uyarlanması ve sınıf öğretmeni adaylarının öz yeterlik inançları, Dokuz Eylül Üniversitesi, Buca Eğitim Fakültesi Dergisi, 27, 63-75.

Taylor, E. (2014). The Correlation Between Self-Efficacy and the Academic Success of Students. A Senior Thesis submitted in partial fulfillment of the requirements for graduation in the Honors Program, Liberty University.

Tunca, N., \& Alkın-Şahin, S. (2014). Öğretmen adaylarının bilişötesi (Üst Biliş) öğrenme stratejileri ile akademik öz yeterlik inançları arasındaki ilişki, Anadolu Journal of Education Sciences İnternational, 4(1), 47-56.

Ünlü, İ., Kaşkaya, A., \& Kızılkaya, M. F. (2017). Sosyal Bilgiler öğretmen adaylarının öz yeterlik inançlarının çeşitli değişkenler açısından incelenmesi, Ahi Evran Üniversitesi, Kırşehir Eğitim Fakültesi Dergisi, 18(2), 651-668.

Üredi, I., \& Üredi L. (2006). İlköğretim 8. Sınıf Öğrencilerinin Öz-düzenleme Stratejileri ve Motivasyonel İnançlarının Matematik Başarısını Yordama Gücü. Mersin Eğitim Fakültesi Dergisi, 1, 250-260.

Yağcı, U., \& Aksoy, V. (2015). Müzik öğretmeni adaylarının öz yeterlikleriyle öğretmenlik öz yeterlikleri arasındaki ilşkinin incelenmes, Mehmet Akif Ersoy Üniversitesi, Ĕ̈itim Fakültesi Dergisi, 33, 89-104.

Yalmancı, S. G., \& Aydın, S. (2014). Fen Bilgisi Öğretmen Adaylarının Akademik Öz-Yeterlik Algılarının İncelenmesi. Kafkas Üniversitesi, Kafkas Ĕgitim Araştırmaları Dergisi, 1(1).

Yalnız, A. (2014). Akademik Öz -Yeterlik: Olumlu ve olumsuz duygulanımın yordayıcı rolü, Eğitim ve Öğretim Araştırmaları Dergisi, 3(2), 95-101.

Yaşar, Ş., Gültekin, M., \& Ersoy, A. (2006). Self-efficacy perceptions of teacher candidates in the primary school teacher training program regarding subject area teaching, Paper presented at The Second World Curriculum Studies Conference, May 21-24, 2006 Tampere, Finland.

Yenilmez, K. (2016). Öğretmen adaylarının öz yeterlikleri ve matematik öğretimine yönelik öz yeterliklerin bazı değişkenler açısından incelnemesi, Dicle Üniversitesi, Ziya Gökalp Eğitim Fakültesi Dergisi, 324-332.

Y1lmaz İ, Yoncalık O., \& Ulucan, H. (2010). 11th International Sports Sciences Congress: Examining the belief of academic self-efficacy and teacher selfefficacy of physical education teacher candidates in terms of various variables. Antalya: Gazi University.

Yılmaz, M., Gürçay, D., \& Ekici, G. (2007). Akademik öz yeterlik ölçeğinin Türkçe’ye uyarlanması, Hacettepe Üniversitesi, Eğitim Fakültesi Dergisi(H.U. Journal of Education), 33, 253-259.

Zajacova, A., Lynch, S. M., \& Espenshadet, T. J. (2005). Self-efficacy, stres and academic succes in college. Research in Higher Education, 46(6), 677-698. https://doi.org/10.1007/s11162-004-4139-z

\section{Copyrights}

Copyright for this article is retained by the author(s), with first publication rights granted to the journal.

This is an open-access article distributed under the terms and conditions of the Creative Commons Attribution license (http://creativecommons.org/licenses/by/4.0/). 